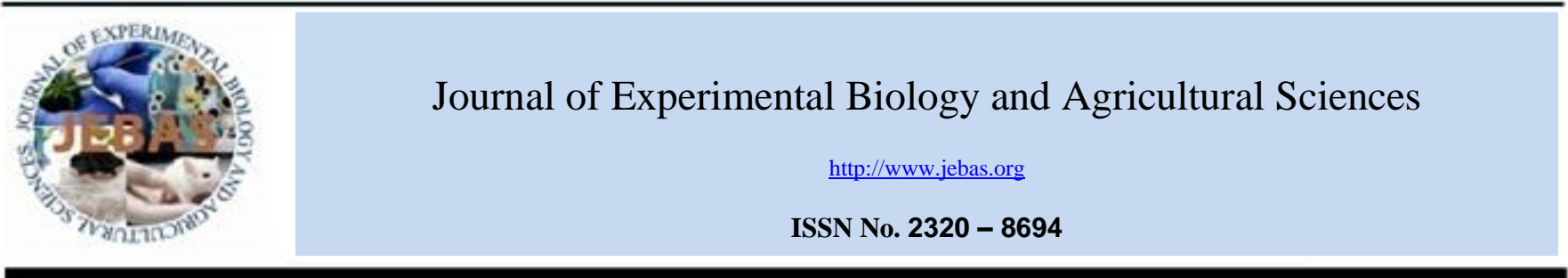

\title{
DECIPHERING THE PHARMACOLOGICAL INSIGHTS OF FRACTIONATED ELATOSTEMA PAPILLOSUM WED. AND HOLIGARNA LONGIFOLIA ROXB. THROUGH IN VITRO AND IN VIVO STUDIES
}

\author{
Md. Zia Uddin ${ }^{1,2}$ (D), Md. Sohel Rana ${ }^{2}$ (D), Subrata Chowdhury ${ }^{1}$, Arkajyoti Paul ${ }^{1}$ (iD), \\ Shahadat Hossain ${ }^{3}$ (D), Talha Bin Emran ${ }^{1, *}$ (D), Kuldeep Dhama ${ }^{4, *}$ (D)
}

${ }^{1}$ Department of Pharmacy, BGC Trust University Bangladesh, Chittagong-4381, Bangladesh

${ }^{2}$ Department of Pharmacy, Jahangirnagar University, Savar, Dhaka-1342, Bangladesh

${ }^{3}$ Atomic Energy Centre, East Nasirabad, Chittagong-4209, Bangladesh

${ }^{4}$ Division of Pathology, ICAR-Indian Veterinary Research Institute, Izatnagar, Bareilly-243 122, Uttar Pradesh, India

Received - March 15, 2021; Revision - April 08, 2021; Accepted - April 20, 2021

Available Online - April 25, 2021

DOI: http://dx.doi.org/10.18006/2021.9(2).189.199

\section{KEYWORDS \\ Holigarna longifolia \\ Elatostema papillosum \\ Antibacterial \\ Anti-arthritic}

Hyperglycemia

\begin{abstract}
The present research intended to explore the biological activities, namely acute toxicity test and hypoglycemic as well as in vitro anti-arthritic along with the antibacterial activity of crude methanol extracts with its different soluble fractions like petroleum ether (PESF), carbon tetrachloride (CTCSF), chloroform (CSF) and aqueous soluble fraction (AQSF) of Holigarna longifolia and Elatostema papillosum. Phytochemical screening was performed by established protocols. Acute toxicity and hypoglycemic effects were performed in experimental and alloxan-induced diabetic rats. In vitro antiarthritic and antibacterial activity were conducted by protein denaturation inhibitory and disc diffusion methods. It was observed that no rats exhibit any lethality types, which reveal the safety of plant fractionates. It was also seen that both plants' fractionates showed significant $(p<0.01)$ activity on hyperglycemia compared to standard. Upon investigation, it was observed that crude methanol and its CS fraction of E. papillosum and only CS fraction of $H$. longifolia significantly ( $<<0.05$ ) inhibited denaturation of bovine serum albumin protein compared to standard diclofenac sodium. Moreover, it was observed that crude methanol extract and its CS fraction of E. papillosum showed significant inhibitory action on all Gram-positive bacteria's growth. In contrast, the PES fraction highlighted an inhibitory zone of 26.7 and $24.7 \mathrm{~mm}$, respectively, towards $B$. subtilis and $S$. aureus. This study provides some support to explain the traditional uses of H. longifolia and E. papillosum.
\end{abstract}

* Corresponding author

E-mail: kdhama@ @rediffmail.com (Kuldeep Dhama); talhabmb@bgctub.ac.bd (Talha Bin Emran)

Peer review under responsibility of Journal of Experimental Biology and Agricultural Sciences.

Production and Hosting by Horizon Publisher India [HPI] (http://www.horizonpublisherindia.in/).

All rights reserved.
All the articles published by Journal of Experimental Biology and Agricultural Sciences are licensed under a Creative Commons Attribution-NonCommercial 4.0 International License Based on a work at www.jebas.org.

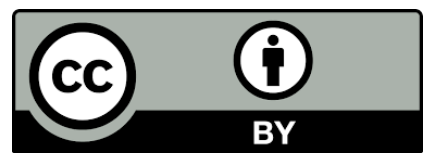




\section{Introduction}

World Health Organization (WHO) says, about $80 \%$ of the world population specially in developing countries are mostly depend on the traditional medicine from plants for their healthcare (Rahman et al., 2013; Biswas et al., 2014) in the form of tea, decoction or extracts with water, milk (or) alcohol (Bristy et al., 2020) and WHO has also recommended to use plants as medicines where the conventional medicine is not easily available (Rakib et al., 2020). The holistic practice of medicine like Ayurveda, homeopathy, siddha, unani are in practice of using the plant herbal formulations to treat various ailments (Uddin et al., 2019). Diabetes is one of the most prevalent metabolic disorders characterized with elevated level of blood glucose and inappropriate metabolism. Insulin is released by the pancreas which utilizes blood glucose into the cells for energy production. Without presence of insulin glucose level gets elevated in blood and soon after eliminated through the urine. Diabetes also causes different types of additional problems like retinopathy, neuropathy and nephropathy. These problems commonly originate due to DNA damage caused by free radical generation (Tareq et al., 2020). It is also associated with high heart risks caused by means of improper cholesterol metabolism which in turn leads to hyperlipidemia (O'Brien et al., 1998; Shifah et al., 2020) and hence it is necessary to search for a molecule which can lowers blood glucose level, scavenges free radical and decrease hyperlipidemia. This need prompted us the current investigation. In the modern world, human beings are affected by numerous metabolic diseases such as diabetes, cancer, arthritis, gastrointestinal diseases etc. Among the metabolic diseases, one of disease affecting most of the people is arthritis. Likewise, arthritis is one of the oldest diseases and it a systemic inflammatory disease which mainly affects the joints (Subramoniam et al., 2013). The usual age of onset of arthritis is between 25 and 50 which occur more frequently in the people of age group $40 \mathrm{~s}$ and $50 \mathrm{~s}$ (Patwardhan \& Hopper, 1992; Yesmin et al., 2020).

The most commonly used drugs in the conventional modern medicine are non-steroidal anti-inflammatory drugs (NSAIDS) which shows potent injurious effects like stomach irritation, malfunction of the kidney, urticaria, liver disorders, hematological abnormalities and gastrointestinal problems which includes ulcers, bleeding, heartburn, diarrhea, retention of fluid and perforation of stomach or intestine (Yesmin et al., 2020). Rheumatoid arthritis is a chronic disease characterized by the hyperactive state of some specific reactions related with immune system, chronic synovitis and in most cases, it causes deposition of rheumatoid factor (RF) an auto antibodies to self-antigens (Lipsky, 2008; Akter et al., 2020). It affects about $1 \%$ of world population (Silman \& Pearson, 2002) and the prevalence of RA is highly in adult men of age between 30-50 years. The prevalence of RA in women are about $0.8 \%$, it is more prevalent in women than men. The conventional modern medicine is just aimed at reducing the pain, inflammation, damage to articular structure etc. but it is not totally curative. Based on the traditional information many of the plant extracts (or) and active fractions were tested in experimental animal models of arthritis and inflammation.

Infectious diseases are major causes of morbidity and mortality in the developing world and accounts for about $50 \%$ of all deaths (Emran et al., 2015). Wide ranges of plants were extensively used for multidimensional diseases. These benefits provide form their big content on bioactive compounds (Cheruvanky, 2004; Kumar et al., 2013). With the development in techniques and recent researches, various compounds in plants has been proved to have a varied pharmacological activity such as neuroprotective, antidiabetic, anti-inflammatory, anti-arthritic, antinociceptive, antioxidant, antidiarrhoeal, antimicrobial, and cytotoxic properties. In this context, this is a matter of interest to evaluate the pharmacological properties like antibacterial, anti-arthritic, antidiabetic activities and toxicity study of different fractionated extracts of $H$. longifolia and E. papillosum.

\section{Materials and Methods}

\subsection{Plants Sample}

Holigarna longifolia Roxb. (locally known as Borola/Katebel), a member of Anacardiaceae family and Elatostema papillosum Wed., a member of Urticaceae were used in this context as plants of interest. Both plant species occurs in the forest areas of Sylhet, Chattogram and Chattogram Hill tracts. Traditionally H. longifolia is used for the healing of nasal polyps whereas E. papillosum is used in the treatment of cirrhosis, liver cancer, paralysis, rheumatic arthritis, rheumatism and scabies (Uddin, 2002; Uddin et al., 2019). These plants were chosen for the current study as majority of their pharmacological properties, isolation of phytoconstituents as well as elemental profile exploration still remains in unexplored condition.

\subsection{Preparation of Crude Extract and It's Different Fractionates}

Leaves of E. papillosum and H. longifolia were collected from Chittagong Hill tracts area. Both plants were taxonomically authenticated by Department of Botany, University of Chittagong. Methanol extracts of both plants were extracted through cold extraction process by following standard procedures with some modifications by using rotary vacuum evaporator at a temperature of $\left(40-45{ }^{\circ} \mathrm{C}\right)$ under compact pressure. Concentrated methanol extracts (ME) of both plants were partitioned by the modified Kupchan method (Muhit et al., 2010) and the resultant soluble fractionates i.e., PESF, CTCSF, CSF and AQSF were isolated. 


\subsection{Phytochemical Group Analysis}

Phytochemical group tests were done to ensure the presence of secondary metabolic constituents which was identified by characteristic color changes using standard procedures described by Ghani, Sofowara, Trease and Evans and Harborne (Ghani, 2003; Trease \& Evans, 1989; Sofowara, 1993; Harborne, 1973).

\subsection{Experimental Animals}

Wistar Albino rats of both sex of 150-200 g weight were employed in this research. The rats were nurtured in a wire meshed plastic cages prior to commencement of the experiment for 4 to 5 days at ambient temperature $\left(28 \pm 5{ }^{\circ} \mathrm{C}\right)$. During the regimen of experiment, recommended pellet diet with water ad libitum were given to the rats as normal diet. Animals were handled and maintained in accordance with the guiding principle provided by Institutional Animal Ethics Committee of the Faculty of Biological Science, University of Chittagong, Bangladesh (AERB/FBS/UC/02, 2015).

\subsection{Acute Toxicity Test}

Acute toxicity study has been performed through the method described by Harizal et al. (2010). In vivo acute toxicity study was employed by 423 guiding principles (Acute toxicity class method) set down by OECD (Organization of Economic Cooperation and Development). Albino rats with sound physical state were indiscriminately alienated into eight classes where each class had six (6) rats. The animals were reserved fasting for the night with plenty of water, thereafter with extracts of E. papillosum and $H$. longifolia with increasing doses (100, 200, 300, 400, 500, 600, 700 , and $800 \mathrm{mg} / \mathrm{kg}$ body weight) with the aid of intragastric tube in order to determine the safe doses by up and down staircase method.

\subsection{Anti-diabetic Activity}

Hypoglycemic effects of both plants fractionates have been investigated on diabetic rats by the method prescribed by Kannur et al. (2006).

\subsubsection{Experimental Design}

A total of 138 male albino Wistar rats were employed and arbitrarily separated into 23 sets of $\operatorname{six}(n=6)$ rats in every set:

Group I: Normal control (untreated with dimethyl sulfoxide [DMSO, $3 \mathrm{ml} / \mathrm{kg}]$ ).

Group II: Diabetic control (alloxan administered).

Group III: Diabetic control + Glibenclamide $(0.5 \mathrm{mg} / \mathrm{kg}$ body weight once a day orally for 10 days).
Group IV: Diabetic control + E. papillosum methanol extract.

Group V: Diabetic control + E. papillosum PES fraction.

Group VI: Diabetic control + E. papillosum CTS fraction.

Group VII: Diabetic control + E. papillosum CS fraction.

Group VIII: Diabetic control + E. papillosum AQS fraction.

Group IX: Diabetic control + H. longifolia methanol extract.

Group X: Diabetic control + H. longifolia PES fraction.

Group XI: Diabetic control + H. longifolia CTS fraction.

Group XII: Diabetic control $+H$. longifolia CS fraction.

Group XIII: Diabetic control + H. longifolia AQS fraction.

Group XIV: Normal rats receiving E. papillosum methanol extract.

Group XV: Normal rats receiving E. papillosum PES fraction.

Group XVI: Normal rats receiving E. papillosum CTS fraction.

Group XVII: Normal rats receiving E. papillosum CS fraction.

Group XVIII: Normal rats receiving E. papillosum AQS fraction.

Group XIX: Normal rats receiving H. longifolia methanol extract.

Group XX: Normal rats receiving H. longifolia PES fraction.

Group XXI: Normal rats receiving $H$. longifolia CTS fraction.

Group XXII: Normal rats receiving $H$. longifolia CS fraction.

Group XXIII: Normal rats receiving H. longifolia AQS fraction.

Oral doses of $400 \mathrm{mg} / \mathrm{kg}$ for 3 hours for all extracts were used in this experiment. The extracts were administered to the respective groups through oral route using intragastric tube for 3 hours.

\subsubsection{Induction of Experimental Diabetes and Treatment}

An intraperitoneal solution of Alloxan monohydrate $(10 \mathrm{mg} / \mathrm{ml})$ was induced in the rats within the interval of 5 mins at a dose of 50 $\mathrm{mg} / \mathrm{kg}$ body weight. Ice-cold citrate buffer of $0.1 \mathrm{M}$ of $\mathrm{pH} 4.5$ was used for preparing the solution of alloxan. Alloxan was chosen to induce diabetes due to its availability and widely reported in previous research (Soto et al., 1994; Doss \& Dhanabalan, 2008). After $48 \mathrm{~h}$ of administration, diabetic model rats with hyperglycemia and glycosuria were taken for the experiment. 
Table 1 Presence of phytochemicals in crude methanol extracts of E. papillosum and H. longifolia

\begin{tabular}{|c|c|c|c|}
\hline \multirow{2}{*}{ Serial No. } & \multirow{2}{*}{ Secondary metabolites } & \multicolumn{2}{|c|}{ Name of the species } \\
\hline & & E. papillosum & H. longifolia \\
\hline 1 & Alkaloids & + & - \\
\hline 2 & Flavonoids & + & + \\
\hline 3 & Steroids & + & + \\
\hline 4 & Tannins & + & - \\
\hline 5 & Saponins & + & + \\
\hline 6 & Phlobatannins & - & - \\
\hline 7 & Glycosides & + & + \\
\hline
\end{tabular}

"+" indicates presence of secondary metabolites whereas “---" denotes the absence of secondary metabolites

Table 2 Hypoglycemic actions of different fractionates of E. papillosum and H. longifolia compared to standard glibenclamide

\begin{tabular}{|c|c|c|c|c|c|c|c|c|}
\hline \multirow[b]{3}{*}{ Sample } & \multicolumn{8}{|c|}{ Hypoglycemic Activity (mmol/L) } \\
\hline & \multicolumn{4}{|c|}{ E. papillosum (400 mg/kg) } & \multicolumn{4}{|c|}{ H. longifolia (400 mg/kg) } \\
\hline & Initial & $\begin{array}{c}60 \\
\min \end{array}$ & $120 \mathrm{~min}$ & $\begin{array}{l}180 \\
\min \end{array}$ & Initial & $\begin{array}{c}60 \\
\min \end{array}$ & $120 \mathrm{~min}$ & $180 \mathrm{~min}$ \\
\hline ME & $\begin{array}{c}15.5 \pm \\
1.23\end{array}$ & $13.5 \pm 1.58$ & $12.0 \pm 1.23$ & $11.3 \pm 1.91$ & $16.8 \pm 1.45$ & $12.9 \pm 1.24$ & $12.2 \pm 1.31$ & $11.2 \pm 1.55$ \\
\hline PESF & $\begin{array}{c}14.4 \pm \\
1.76\end{array}$ & $14.4 \pm 1.23$ & $13.3 \pm 1.44$ & $12.1 \pm 1.51$ & $16.4 \pm 1.67$ & $12.7 \pm 1.08$ & $12.1 \pm 1.12$ & $11.3 \pm 1.25$ \\
\hline CTCSF & $\begin{array}{c}16.8 \pm \\
1.67\end{array}$ & $13.5 \pm 1.76$ & $12.8 \pm 1.14$ & $12.3 \pm 1.57$ & $16.1 \pm 1.12$ & $13.4 \pm 1.19$ & $12.3 \pm 1.31$ & $11.3 \pm 1.23$ \\
\hline CSF & $\begin{array}{c}16.2 \pm \\
1.79 \\
\end{array}$ & $12.2 \pm 1.31$ & $11.9 \pm 1.49$ & $10.6 \pm 1.33$ & $16.7 \pm 1.71$ & $13.0 \pm 1.54$ & $12.7 \pm 1.33$ & $11.2 \pm 1.35$ \\
\hline AQSF & $\begin{array}{c}15.9 \pm \\
1.32\end{array}$ & $11.1 \pm 1.12$ & $10.9 \pm 1.47$ & $9.3 \pm 1.11$ & $15.7 \pm 1.14$ & $13.5 \pm 1.13$ & $12.8 \pm 1.56$ & $12.3 \pm 1.67$ \\
\hline \multicolumn{5}{|c|}{ Control ( $1 \%$ Tween- 80 solution in saline) } & $16.7 \pm 1.34$ & $6.8 \pm 1.67$ & $6.2 \pm 1.12$ & $5.6 \pm 1.32$ \\
\hline \multicolumn{5}{|c|}{ Standard ( $5 \mathrm{mg} / \mathrm{kg}$ glibenclamide) } & $16.3 \pm 1.42$ & $3.4 \pm 1.21$ & $2.6 \pm 1.21$ & $2.5 \pm 1.78$ \\
\hline
\end{tabular}

SEM = standard error of mean, $\mathrm{n}=5$. Values in the table are articulated as mean \pm SEM, $* \mathrm{p}<0.05$, significantly different in comparison with standard. The data was analyzed by ANOVA followed by Dunnett's test

Table 3 Statistical analysis of hypoglycemic effects of different fractionates of E. papillosum and H. longifolia compared to standard glibenclamide

\begin{tabular}{|ccccc|}
\hline Code $n o$ & E. papillosum & & H. longifolia \\
Level of significance & p-value & Level of significance \\
\hline STD & 0.0214 & Statistically significant & 0.0214 & Statistically significant \\
\hline ME & 0.9345 & Statistically not significant & 0.885 & Statistically not significant \\
\hline PESF & 0.7687 & Statistically not significant & 0.6672 & Statistically not significant \\
\hline CTCSF & 0.7364 & Statistically not significant & 0.7241 & Statistically not significant \\
\hline CSF & 0.6431 & Statistically not significant & 0.6998 & Statistically not significant \\
\hline AQSF & 0.5451 & Statistically not significant & 0.6412 & Statistically not significant \\
\hline
\end{tabular}

Journal of Experimental Biology and Agricultural Sciences 


\subsubsection{Hypoglycemic Activity Test}

Diabetic rats were reserved fasted for 8 hours. After accomplishment of fasting stage, fasting blood glucose (FBG) level of the rats were estimated by glucometer kit (Clever Check, Germany). Consequently, diabetes was introduced by intraperitoneal administration of alloxan at a dose of $(70 \mathrm{mg} / \mathrm{kg})$ (Aruna et al., 1999). Blood was drawn after $1 \mathrm{~h}, 2 \mathrm{~h}$ and $3 \mathrm{~h}$ consecutively from each rat by tail snipping for determining diabetic blood glucose. Animals with blood glucose level $\geq 10$ $\mathrm{mmol} / \mathrm{dl}$ were marked as hyperglycemic and used for the study.

\subsection{In vitro Anti-arthritic Activity}

Following subsequent steps were maintained for the evaluation of anti-arthritic activity (i) $0.5 \mathrm{ml}$ of test solution, control solution and product control were made of $0.45 \mathrm{ml}$ of Bovine serum albumin (5\% w/v aqueous solution) and $0.05 \mathrm{ml}$ of test solution (250 $\mu \mathrm{g} / \mathrm{ml}), 0.05 \mathrm{ml}$ of distilled water along with $0.05 \mathrm{ml}$ of test solution $(250 \mu \mathrm{g} / \mathrm{ml})$ respectively (ii) Similarly $0.5 \mathrm{ml}$ of standard solution was made with $0.45 \mathrm{ml}$ of Bovine serum albumin and 0.05 $\mathrm{ml}$ of diclofenac sodium $(250 \mu \mathrm{g} / \mathrm{ml})$. All solutions were accustomed to $\mathrm{pH} 6.3$ with $1 \mathrm{~N} \mathrm{HCl}$. All solutions were kept at 37 ${ }^{\circ} \mathrm{C}$ for 20 minutes and heat was augmented to $57^{\circ} \mathrm{C}$ for 3 minutes. Subsequent to cool, $2.5 \mathrm{ml}$ of phosphate buffer was added to all of the solutions. Finally optical density was measured by UV-Visible spectrophotometer at the wavelength of $416 \mathrm{~nm}$ (Mizushima \& Kobayashi, 1968; Aruoma, 1998). The percent (\%) of protein denaturation inhibition can be expressed as,

Percent protein denaturation inhibition

$=\frac{100-(\text { absorbance of test solution }- \text { optical density of product control })}{\text { optical density of test control })] \times 100}$

Here control stands for $100 \%$ denaturation of protein.

\subsection{Antibacterial Activity}

Antibacterial activity of plant extracts was evaluated by disc diffusion method explained by Bauer et al. (1966). In this study four Gram +ve and six Gram -ve bacterial strains were used. A measured amount of crude extract, different fractionates (400 $\mu \mathrm{g} / \mathrm{disc})$ and Ciprofloxacin $(30 \mu \mathrm{g} / \mathrm{disc})$ as standard antibiotic were used in the present study. The bacteria cultures were nurtured in Nutrient Broth medium at $37^{\circ} \mathrm{C}$. After 6 hours, culture of every microorganism was inoculated on the plane of Mueller-Hinton agar plates. Filter paper discs of $4 \mathrm{~mm}$ in diameter were then soaked with esteemed quantity of test substances (400 $\mu \mathrm{g} / \mathrm{disc})$ by using micropipette. Discs of test sample were then sited on agar plate medium unvaryingly germen with the experimental microorganisms. Discs drenched in relevant solvent were marked as positive control. The plates were then reserved at $4{ }^{\circ} \mathrm{C}$ temperature for two to four hrs to permit highest distribution of molecule. The experimental plates were subsequently kept in $37^{\circ} \mathrm{C}$ for 24 hours to allocate utmost expansion of tested microorganisms. A clear distinct zone around the disc reflects the antibacterial activity of test materials.

\subsection{Statistical Analysis}

Statistical investigation was evaluated with the help of Graph Pad Prism software package, version 7.0. All the statistics were articulated as mean \pm standard error mean (SEM). The comparisons within groups were evaluated utilizing independent student $t$-test and one-way analysis of variance (ANOVA). The values of $\mathrm{p}<0.05$ or $\mathrm{p}<0.01$ were regarded as statistically significant.

\section{Results}

\subsection{Screening of Phytochemicals}

From phytochemical screening it was observed that E. papillosum contains alkaloids, tannins, saponins, glycosides and higher percentage of flavonoids and steroids whereas $H$. longifolia contains flavonoids, steroids, glycosides and higher percentage of saponins. The results of table 1 showed the presence of phytochemicals in crude methanol extracts of E. papillosum and $H$. longifolia.

\subsection{Acute Toxicity Study}

Acute toxicity study was employed on healthy male albino rats. The animals were reserved fasting for the night with plenty of water supply, thereafter with extracts of E. papillosum and $H$. longifolia with increasing doses $(100,200,300,400,500,600$, 700 , and $800 \mathrm{mg} / \mathrm{kg}$ body weight) with the aid of intragastric tube in order to determine the safe doses. No lethality and death was observed which indicates that both plant extracts were showed no toxicity in rats

\subsection{Anti-diabetic Activity}

All fractionated extracts of both plants were administered serially to all 23 groups of rats and then diabetic level was measured after $1^{\text {st }}, 2^{\text {nd }}$, and $3^{\text {rd }}$ hour using glucometer. It was observed that all fractionates showed no hypoglycemic effects on alloxan induced diabetic rats. Here all the statistics were presented as mean \pm SEM (standard error mean). Table 2 and 3 presents the results of antidiabetic activity.

\subsection{Anti-arthritic Activity}

In this investigation it was observed that crude methanol and its CS fraction of E. papillosum showed statistically significant ( $<$ 0.05) and only CS fractions of $H$. longifolia showed statistically significant $(\mathrm{p}<0.05)$ anti-arthritic activity compared to standard diclofenac sodium. 
Table 4 Percent inhibition of denaturation of protein by different fractionates of E. papillosum and H. longifolia compared to standard diclofenac sodium

\begin{tabular}{|ccccccc|}
\hline Sample & $\begin{array}{c}\text { Concentration } \\
(\mathrm{mg} / \mathrm{ml})\end{array}$ & E. papillosum & p-value & H. longifolia & p-value \\
\hline ME & 200 & $54.34 \pm 2.34^{*}$ & 0.038 & $23.54 \pm 2.32$ & 0.065 \\
\hline PESF & 200 & $29.45 \pm 1.34$ & 0.057 & $18.67 \pm 1.17$ & 0.059 \\
\hline CTCSF & 200 & $21.24 \pm 3.67$ & 0.076 & $12.23 \pm 1.59$ & 0.097 \\
\hline CSF & 200 & $46.48 \pm 2.43^{*}$ & 0.029 & $38.18 \pm 2.78^{*}$ & 0.043 \\
\hline AQSF & 200 & $12.3 \pm 2.95$ & 0.094 & $13.87 \pm 2.63$ & 0.091 \\
\hline Diclofenac-Na & 50 & & $74.93 \pm 1.12$ & & \\
\hline
\end{tabular}

$\mathrm{SEM}=$ standard error of mean, $\mathrm{n}=5$. Values in the table are articulated as mean \pm SEM, $* \mathrm{p}<0.05$, significantly different in comparison with standard. The data was analyzed by ANOVA followed by Dunnett's test

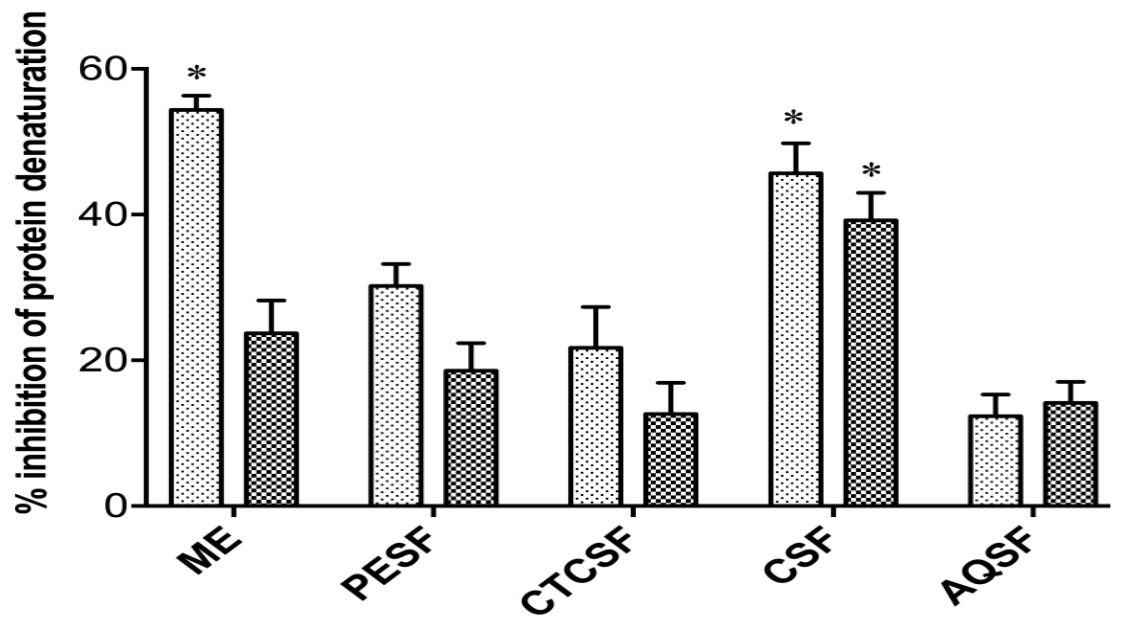

Figure 1 Comparison of the activity of different fractionates of E. papillosum and H. longifolia on the percentage of inhibition of protein denaturation

Here all the values are articulated as mean \pm SEM. The results are given in Table 4. Figure 1 represents the comparison of the activity of different fractionates of E. papillosum and H. longifolia on the percentage of inhibition of protein denaturation.

\subsection{Antibacterial Activity}

Antibacterial activity against gm (+) ve and gm (-) ve bacterial type have been carried out through disc diffusion method. Here methanol extract and CS fractions showed significant zone of inhibition in petri plate against gm (+) ve bacteria whereas PES fraction of $E$. papillosum showed moderate activity towards $B$. subtilis and $S$. aureus and all fractionates exhibited poor activity towards gm (-) ve bacterial type. But all the fractionates of $H$. longifolia showed poor activity against all $\mathrm{gm}(+)$ ve bacteria and exhibited poor activity towards all gm (-) ve bacterial type compared to standard ciprofloxacin. The results are showed in table 5 .

\section{Discussion}

Medicinal plants are part and parcel of human society to combat diseases from the dawn of civilization. The majority of our population, particularly those living in villages, depends largely on herbal remedies. A good number of herbal remedies have stood the test of time, particularly for treating allergic, metabolic and degenerative diseases associated with ageing. However, very few scientific data regarding their identity and effectiveness of these herbs were available except that in the treatise of Ayurveda and Unani medicine (Ahmed et al., 2019; Banu et al., 2020; Barua et al., 2020; Uddin et al., 2021). 
Table 5 Zone of inhibition showed against gm (+) ve and gm (-) ve bacterial type by different fractionates of E. papillosum and H. longifolia compared to standard ciprofloxacin.

\begin{tabular}{|c|c|c|c|c|c|c|c|c|c|c|c|}
\hline \multirow{2}{*}{\multicolumn{2}{|c|}{ Bacterial Type }} & \multicolumn{4}{|c|}{ Gram +ve type } & \multicolumn{6}{|c|}{ Gram -ve type } \\
\hline & & \multirow{2}{*}{$\begin{array}{c}\text { B. } \\
\text { cereus }\end{array}$} & \multirow{2}{*}{$\begin{array}{c}B . \\
\text { megaterium }\end{array}$} & \multirow{2}{*}{$\begin{array}{c}\text { B. } \\
\text { subitilis }\end{array}$} & \multirow{2}{*}{$\begin{array}{c}\text { S. } \\
\text { aureus }\end{array}$} & \multirow{2}{*}{$\begin{array}{l}E . \\
\text { coli }\end{array}$} & \multirow{2}{*}{$\begin{array}{c}P . \\
\text { aeruginosa }\end{array}$} & \multirow{2}{*}{$\begin{array}{c}\text { S. } \\
\text { paratyphi }\end{array}$} & \multirow{2}{*}{$\begin{array}{c}S . \\
\text { typhi }\end{array}$} & \multirow{2}{*}{$\begin{array}{l}\text { S. } \\
\text { dysenteriae }\end{array}$} & \multirow{2}{*}{$\begin{array}{c}V . \\
\text { cholera }\end{array}$} \\
\hline & & & & & & & & & & & \\
\hline & $\mathrm{ME}$ & 25.1 & 21.1 & 27.4 & 24.3 & 12.4 & 15.7 & 17.4 & 12.7 & 13.5 & 14.1 \\
\hline $\begin{array}{c}(E . \\
\text { papillosum })\end{array}$ & PESF & 16.5 & 17.5 & 26.7 & 24.7 & 13.6 & 14.6 & 12.4 & 11.2 & 13.1 & 10.2 \\
\hline \multirow{4}{*}{$\begin{array}{l}\text { Diameter of } \\
\text { Zone of } \\
\text { Inhibition } \\
(\mathrm{mm})\end{array}$} & CTSF & 5.7 & 5.3 & 4.6 & 1.2 & $\begin{array}{ll}--- \\
\end{array}$ & --- & --- & 2.8 & $\begin{array}{ll}-- \\
\end{array}$ & 1.4 \\
\hline & CSF & 22.3 & 24.6 & 26.3 & 21.6 & 13.4 & 14.6 & 10.3 & 16.7 & 13.8 & 11.6 \\
\hline & AQSF & --- & --- & 8.4 & --- & $\begin{array}{ll}-- \\
\end{array}$ & 8.9 & --- & --- & --- & 3.9 \\
\hline & $\mathrm{ME}$ & 10.3 & 12.4 & 13.2 & 18.8 & 3.6 & 5.4 & 3.7 & 5.8 & 4.8 & 5.2 \\
\hline $\begin{array}{c}(H . \\
\text { longifolia })\end{array}$ & PESF & 6.2 & 8.5 & 9.3 & 10.2 & 5.3 & 4.9 & 6.4 & 3.5 & 3.7 & 5.4 \\
\hline \multirow{3}{*}{$\begin{array}{l}\text { Diameter of } \\
\text { Zone of } \\
\text { Inhibition } \\
(\mathrm{mm})\end{array}$} & CTSF & --- & 2.8 & 3.3 & $\begin{array}{l}-- \\
\end{array}$ & --- & --- & 2.7 & 2.2 & --- & --- \\
\hline & CSF & 11.5 & 16.8 & 15.9 & 19.8 & 10.1 & 9.2 & 14.4 & 10.7 & 14.9 & 10.8 \\
\hline & AQSF & 9.1 & --- & 10.8 & --- & --- & --- & --- & --- & 6.92 & 4.7 \\
\hline \multicolumn{12}{|c|}{$\begin{array}{l}\text { Diameter of Zone of } \\
\text { Inhibition }(\mathrm{mm}) \text { for }\end{array}$} \\
\hline \multicolumn{2}{|c|}{$\begin{array}{c}\text { Standard } \\
\text { Ciprofloxacin }\end{array}$} & 47.3 & 43.3 & 45.6 & 48.3 & 46.3 & 43.6 & 45.6 & 48.6 & 49 & 45.3 \\
\hline
\end{tabular}

In this study, we have conducted various in vivo and in vitro experiments to assess the acute toxicity study, anti-diabetic, antiarthritic and antibacterial activities of methanol extract with its different fractionates like petroleum ether soluble fraction (PESF), carbon tetrachloride soluble fraction (CTCSF), chloroform soluble fraction (CSF) and aqueous soluble fraction (AQSF) of $E$. papillosum, and $H$. longifolia.

Although phytochemicals obtained from medicinal plants were focused on the empiric experience in the past, currently, the scientific evidence regarding the chemical composition and therapeutic properties are regarded as the main focus while isolating several phytochemicals. Expert taxonomists mainly perform the identification and authentication of medicinal plants; however, one of the main disadvantages includes the absence of several phenotypic characteristics. Besides, the products used in traditional medicine are processed in various forms, such as powder, extracts, capsules, and tablets. Therefore, phytochemical characterisation could be used to identify and authenticate several medicinal plants (Dutta et al., 2019; Banu et al., 2020; Jahan et al., 2020).

Nowadays antibiotic resistance is a major challenge in the healthcare sector of the world. Multidrug resistant pathogens have significantly endangered the present antibacterial therapy. This urgency has committed us to search a new source of antimicrobial drugs like plants as they contain variety of bioactive phytochemicals. This study has been conducted to evaluate the antibacterial activity of two medicinal plant extracts against human pathogens (Romero et al., 2005; Boucher et al., 2009). 
Investigation of antibacterial activity was carried out with the help of disc diffusion method and it was observed that crude methanol extract and its CS fraction of E. papillosum showed significant zone of inhibition towards all gm (+) ve bacteria where as PES fraction exhibited 26.7 and $24.7 \mathrm{~mm}$ of zone of inhibition towards B. subtilis and $S$. aureus. But all fractionates of $H$. longifolia showed poor activity against all gm (+) ve bacteria and exhibited poor activity towards all gm (-) ve bacteria compared to standard ciprofloxacin. The difference in activities may be due to the use of different solvent system (Mohan et al., 2016). It has been widely observed and accepted that the different bioactive phytochemicals present in the plants dissolves in different solvent systems (Cowan, 1999).

The protein-denaturation study for determining anti-arthritis activity was performed using bovine serum albumin (BSA). Upon heating BSA exhibits denaturation and antigens are expressed which are linked with type-III hypersensitivity reaction, that leads to some autoimmune diseases such as rheumatoid arthritis, glomerulonephritis, serum sickness and systemic lupus erythematosus (Kishore et al., 2011). Protein denaturation leads to production of autoantigen which is one of the important causes of rheumatoid arthritis. Denaturation may be due to the alteration of electrostatic, hydrogen, hydrophobic and disulfide bonds (Arya et al., 2014). All the extracts had a dose-dependent response in the in vitro anti-arthritic test. It was observed that crude methanol $(\mathrm{p}=$ 0.038) and its CS fraction ( $\mathrm{p}=0.029)$ of E. papillosum and only CS fraction $(\mathrm{p}=0.043)$ of $H$. longifolia significantly $(\mathrm{p}<0.05)$ inhibited denaturation of bovine serum albumin compared to standard diclofenac sodium. The promising activities of the extracts support their uses as remedies for arthritis, rheumatism and other chronic inflammatory conditions (Elisha et al., 2016).

Before going to in vivo studies acute toxicity study on rats were done to determine whether the fractionated extracts are safe or not. Here both plant fractionates was done by applying higher doses $(100,200,300,400,500,600,700$, and $800 \mathrm{mg} / \mathrm{kg}$ body weight) of all fractionates of both plants on experimental rats and it was observed that no rats exhibit any types of lethality or abnormalities which reveals about the safety of plant fractionates.

Researchers who work with diabetes and related disease are still trying to develop a safer medicines for diabetes (Banagar et al., 2013). The development of modern treatment methods requires animal models that mimic the range of pathophysiological changes visualized in diabetic humans. Here in vivo hypoglycemic activity was performed in alloxan-induced diabetic rats. And it was seen that fractionates of both plant showed insignificant $(\mathrm{p}>0.01)$ activity against hyperglycemia in diabetic rats compared to standard glibenclamide which indicates that fractionates of both plants have no hypoglycemic effect against alloxan induced diabetic rats. In, in vitro anti-arthritic activity percent inhibition of protein denaturation was estimated spectrophotometrically. From phytochemical screening it was observed that E. papillosum contains alkaloids, tannins, saponins, glycosides and higher percentage of flavonoids and steroids whereas $H$. longifolia contains flavonoids, steroids, glycosides and higher percentage of saponins. Phytochemicals like terpenoids, phenylpropanoids, flavonoids, coumarins, sterols, and alkaloids present in plant extracts show antibacterial activity (Yan et al., 2006; Li et al., 2008), where as presence of steroids and flavonoids are responsible for anti-arthritic activity of the plant (Tiwari et al., 2011). So, some of these phytochemicals might be concerned behind the experimental activities of E. papillosum and H. longifolia.

\section{Conclusions}

To the best of our knowledge, very few data regarding $E$. papillosum and $H$. longifolia has been published. However, additional studies are compulsory to elucidate the mechanism behind these effects. As previously, no data regarding this plant published, so we may say that both plants may be an exemplary sample for an alternative therapeutic source of drugs. In this regard, we have to elucidate the structure of secondary metabolites present in the plants and emphasise novel compounds as therapeutic components. This report may serve as a footstep on this aspect.

\section{Conflict of interest}

The authors report no conflicts of interest. The authors only are answerable for the content and inscription of the paper.

\section{Acknowledgements}

The authors are thankful to the Department of Pharmacy, Jahangirnagar University, Savar, Dhaka-1342, Bangladesh and Department of Pharmacy, BGC Trust University Bangladesh, Chandanaish, Chittagong-4381, Bangladesh for providing obligatory amenities for this research work.

\section{Author's contribution}

This exertion was employed in teamwork of all authors. All the authors have accepted responsibility for the entire content of this submitted manuscript and approved the submission. Authors MZU, MSR, SC, and AP performed experiments. Authors MZU and SC collected the plants and prepared the extracts and fractions. MZU and AP performed the anti-arthritic and antibacterial activity. MZU and MSR performed the anti-diabetic activity and hypoglycemic activity. MZU, SC, and AP performed statistical analysis. MZU, MSR, SH, SC, and AP conceived the study and designed the experimental procedures. MSR and SH designed, planned and supervised the experiments. TBE and $\mathrm{KD}$ acted for all correspondences. MZU, MSR, SH, and AP participated in the 
manuscript draft and has thoroughly checked and revised the manuscript for necessary changes in format, grammar and English standard. All authors read and approved the final version of the manuscript.

\section{References}

Ahmed S, Rakib A, Islam MA, Khanam BH, Faiz FB, Paul A, Chy MNU, Bhuiya NMMA, Uddin MMN, Ullah SMA, Rahman MA, Emran TB (2019) In vivo and in vitro pharmacological activities of Tacca integrifolia rhizome and investigation of possible lead compounds against breast cancer through in silico approaches. Clinical Phytoscience 5:36. DOI: 10.1186/s40816-019-0127-x.

Akter S, Shah M, Tareq AM, Nasrin MS, Rahman MA, Babar ZM, Haque MA, Royhan MJ, Mamun MN, Reza ASMA, Emran TB (2020) Pharmacological effect of methanolic and hydro-alcoholic extract of Coconut endocarp. Journal of Advanced Biotechnology and Experimental Therapeutics 3(3): 171-181.

Aruna RV, Ramesh B, Kartha VN (1999) Effect of betacarotene on protein glycosylation in alloxan induced diabetic rats. Indian Journal of Experimental Biology b(4):399-401.

Aruoma OI (1998) Free radicals, oxidative stress, and antioxidants in human health and disease. Journal of the American Oil Chemists' Society 75: 199-212.

Arya D, Meena M, Neha G, Vidya P (2014) In vitro antiinflammatory and anti-arthritic activity in methanolic extract of Cocculus hirsutus (L.). International Journal of Pharmacy Science and Research 2014 5:1957-1962.

Banagar AV, Shivakumar B, Jayaveera KN (2013) Effect of Xylia dolabriformis leaves extract on high fructose diet induced C57BL/6J ob/ob diabetic mice. International Journal of Pharmacy Science and Research 4(10):4032-45.

Banu N, Alam N, Islam MN, Islam S, Sakib SA, Hanif NB, Chowdhury MR, Tareq AM, Chowdhury KH, Jahan S, Azad A, Emran TB, Simal-Gandara J (2020) Insightful Valorization on Biological Activities of Pani Heloch Leaves through Experimental and Computer-Aided Mechanisms. Molecules 25 (21): 5153.

Barua N, Aziz MAI, Tareq AM, Sayeed MA, Alam N, Alam N, Uddin MA, Lyzu C, Emran TB (2020) In vivo and in vitro evaluation of pharmacological activities of Adenia trilobata (Roxb.). Biochemistry and Biophysics Reports 23: Article ID: 100772. DOI: 10.1016/j.bbrep.2020.100772.
Bauer AW, Kirby WM, Sherris JC, Turck M (1966) Antibiotic susceptibility testing by a standardized single disk method. American Journal of Clinical Pathology 45: 493-496.

Biswas FB, Roy TG, Rahman MA, Emran TB (2014) An in vitro antibacterial and antifungal effects of cadmium (II) complexes of hexamethyl tetra-azacyclotetradecadiene and isomers of its saturated analogue. Asian Pacific Journal of Tropical Medicine 7 (Suppl. 2): S534-S539

Boucher HW, Talbot GH, Bradley JS (2009) Bad bugs, no drugs: no ESKAPE! An update from the Infectious Diseases Society of America. Clinical Infectious Diseases 48(1): 1-12.

Bristy TA, Barua N, Tareq AM, Sakib SA, Etu ST, Chowdhury KH, Jyoti MA, Aziz MAI, Reza ASMA, Caiazzo E, Romano B, Tareq SM, Emran TB, Capasso R (2020) Deciphering the pharmacological properties of methanol extract of Psychotria calocarpa leaves through in vivo, in vitro and in silico approaches. Pharmaceuticals 13 (8): 183.

Cheruvanky H (2004) A history of pathology and laboratory medicine at Baylor University Medical Center. United States Pathology 6(1): 733-741.

Cowan MM (1999) Plant products as antimicrobial agents. Clinical Microbiology Reviews 12(4): 564-582.

Doss A, Dhanabalan R (2008) Anti-hyperglycaemic and Insulin Release Effects of Coccinia grandis (L.) Voigt Leaves in Normal and Alloxan Diabetic Rats. Ethnobotanical Leaflets 12: 1172-1175.

Dutta T, Paul A, Majumder M, Sultan RA, Emran TB (2019) Pharmacological evidence for the use of Cissus assamica as a medicinal plant in the management of pain and pyrexia. Biochemistry and Biophysics Reports 21: 1-8. Article ID: 100715. DOI: 10.1016/j.bbrep.2019.100715.

Elisha IL, Dzoyem JP, Botha FS, Eloff JN (2016) The efficacy and safety of nine South African medicinal plants in controlling Bacillus anthracis Sterne vaccine strain. BMC Complementary Alternative Medicine 16: 5.

Emran TB, Rahman MA, Uddin MMN, Dash R, Hossen MF, Mohiuddin M, Alam MR (2015) Molecular docking and inhibition studies on the interactions of Bacopa monnieri's potent phytochemicals against Staphylococcus aureus. DARU Journal of Pharmaceutical Sciences 23: 26.

Ghani A (2003) Asiatic Society of Bangladesh. (2 ${ }^{\text {nd }}$ Ed.): 138

Harborne JB (1973) Phytochemical methods: A guide to modern techniques of plant analysis. Chapman and Hall Ltd, London: 279. 
Harizal SN, Mansor SM, Hasnan J, Tharakan JKJ, Abdullah J (2010) Acute toxicity study of the standardized methanolic extract of Mitragyna speciosa Korth in Rodent. Journal of Ethnopharmacology 131 (2): 404-409.

Jahan I, Tona MR, Sharmin S, Sayeed MA, Tania FZ, Paul A, Chy MNU, Rakib A, Emran TB, Simal-Gandara J (2020) GC-MS phytochemical profiling, pharmacological properties and in-silico studies of Chukrasia velutina leaves: A novel source for bioactive agents. Molecules 25(15): $3536 . \quad$ DOI: 10.3390/molecules25153536.

Kannur DM, Hukkeri VI, Akki KS (2006) Antidiabetic activity of Caesalpinia bonducella seed extracts in rats. Fitoterapia 77: 546 549 .

Kishore G, Siva G, Sindhu ES (2011) In Vitro Anti-Inflammatory and Anti-Arthritic Activity of Leaves of Physalis Angulata L. Industrial Journal of Pharmacy and Industrial Research 1:211213.

Kumar ABP, Sharma DEA., Varshney CP, Rao CV (2013) Antidiabetogenic and antioxidant effects of Caralluma attenuata extract on streptozotocin induced diabetes in rats. Journal of Pharmacy Research 7: 257-262.

Li YM, Li ZY, Ye M (2008) The chemical compositions and their bioactivities in the different parts of Eupatorium adenophorum Spreng. Journal of Yunnan Agricultural University 23: 42-46.

Lipsky PE (2008) In: Harrison's principles of internal medicine (17 $7^{\text {th }}$ Ed.). Mc. Hill Company, New York, 2: 2083.

Mizushima Y, Kobayashi M (1968) Interaction of antiinflammatory drugs with serum proteins, especially with some biologically active proteins. Journal of Pharmacy and Pharmacology 20:169-173.

Mohan SM, Pandey B (2016) Antimicrobial activity of Oxalis corniculata Linn. International Journal of Science and Research 5(7): $575-578$

Muhit MA, Tareq SM, Apu AS, Basak D, Islam MS (2010) Isolation and identification of compounds from the leaf extract of Dillenia indica Linn. Bangladesh Pharmaceutical Journal 13:4953.

O'Brien T, Nguyen TT, Zimmerman BR (1998) Hyperlipidemia and diabetes mellitus. Mayo Clinic Proceedings 73(10): 969-976.

Patwardhan B, Hopper B (1992) Ayurvedic and future drug development. Journal of Alternative and Complementary Medicine 19: 9-10.
Rahman MA, Emran TB, Islam MS (2013) Antioxidative, antimicrobial and cytotoxic effects of the phenolics of Leea indica leaf extract. Saudi Journal of Biological Sciences 20: 213-225.

Rakib A, Ahmed S, Islam MA, Uddin MMN, Paul A, Chy MNU, Emran TB, Seidel V (2020) Pharmacological studies on the antinociceptive, anxiolytic and antidepressant activity of Tinospora crispa. Phytotherapy Research 34(11):2978-2984.

Romero CD, Chopin SF, Buck G, Martinez E, Garcia M, Bixby L (2005) Antibacterial properties of common herbal remedies of the southwest. Journal of Ethnopharmacology 99(2): 253-257.

Shifah F, Tareq AM, Sayeed MA, Islam MN, Emran TB, Ullah MA, Mukit MA and Ullah M (2020) Antidiarrheal, cytotoxic and thrombolytic activities of methanolic extract of Hedychium coccineum leaves. Journal of Advanced Biotechnology and Experimental Therapeutics 3(1): 77-83.

Silman AJ, Pearson JE (2002) Epidemiology and genetics of rheumatoid arthritis. Arthritis Research 4 (3): 265-272.

Sofowara A (1993) Medicinal plants and traditional medicine in Africa. (2nd Edition). Spectrum Books Limited, sunshine House, Ibadan, Nigeria: Pp.191-289.

Soto C, Muriel P, Reyes JL (1994) Pancreatic lipid peroxidation in alloxan-induced diabetes mellitus. Archives of Medical Research 25(4): 377-380.

Subramoniam A, Madhavachandran V, Gangaprasad A (2013) Review Article: Medicinal plants in the treatment of arthritis. Annals of Phytomedicine 2(1): 3-36.

Tareq AM, Farhad S, Uddin ABMN, Hoque M, Nasrin MS, Uddin MMR, Hasan M,Sultana A,Munira MS, Lyzu C, Hossen SMM, Reza ASMA, Emran TB (2020) Chemical profiles, pharmacological properties, and in silico studies provide new insights on Cycas pectinata. Heliyon 6(6): e04061.

Tiwari P, Kumar B, Kaur M, Kaur G, Kaur H (2011) Phytochemical Screening and Extraction: A Review. Internationale Pharmaceutica Sciencia 1:98- 106.

Trease GE, Evans WC (1989) Pharmacognosy. (11 ${ }^{\text {th }}$ edn.). Brailliar Tiridel and Macmillian Publishers, London, UK.

Uddin MZ, Paul A, Rakib A, Sami SA, Mahmud S, Rana MS, Hossain S, Tareq AM, Dutta M, Emran TB and Simal-Gandara J (2021) Chemical Profiles and Pharmacological Properties with In Silico Studies on Elatostema papillosum Wedd. Molecules 26(4): 809. DOI: 10.3390/molecules26040809. 
Uddin MZ, Rana MS, Hossain S, Dutta E, Ferdous S, Dutta M, Yan QS, Yang J, Li HM (2006) Advances in the studies on the Emran TB (2019) In vivo neuroprotective, antinociceptive, antiinflammatory potential in Swiss albino mice and in vitro antioxidant and clot lysis activities of fractionated Holigarna longifolia Roxb. bark extract. Journal of Complementary and Integrative Medicine 17(2): 1-9.

Uddin SN (2002) Bangladesh National Herbarium: 541, 604. chemical components and bioactivity of Eupatorium adenophorum Spreng as an intruding species. Journal of Beijing Normal University 42: 70-73.

Yesmin S, Paul A, Naz T, Rahman ABMA, Akhter SF, Wahed MII, Emran TB, Siddiqui SA (2020) Membrane stabilization as a mechanism of the anti-inflammatory activity of ethanolic root extract of Choi (Piper chaba). Clinical Phytoscience 6:59.

Journal of Experimental Biology and Agricultural Sciences http://www.jebas.org 